\title{
Ethyl acetate fraction of Calotropis gigantea roots induce apoptosis through increased G2/M and increased expression of caspase-8 in colon cancer WiDr cell line
}

\author{
Roihatul Mutiah ${ }^{1}$, Aty widyawaruyanti ${ }^{2}$, Sukardiman Sukardiman ${ }^{2 *}$ \\ ${ }^{1}$ Departement of Pharmacy, Faculty of Medical and Health Sciences, Universitas Islam Negeri Maulana Malik Ibrahim, Malang Indonesia. \\ ${ }^{2}$ Departement of Pharmacognosy and Phytochemistry, Faculty of Pharmacy, Universitas Airlangga, Surabaya Indonesia.
}

\begin{tabular}{l} 
ARTICLE INFO \\
\hline Article history: \\
Received on: 08/03/2017 \\
Accepted on: 24/04/2017 \\
Available online: 30/07/2017 \\
\hline Key words: \\
Calotropis gigantea, ethyl \\
acetate fraction, apoptosis, \\
cell cycle, caspase-8, WiDr \\
cell.
\end{tabular}

\begin{abstract}
Cell apoptosis is one of important mechanisms and used as target for anticancer drugs. This study aimed at determining the mechanism of apoptosis induced by the most active fraction of Calotropis gigantea root extract in colon cancer cells WiDr. Calotropis gigantea root extract (CGRE) was fractionated using solvents including water, dichloromethane, ethyl acetate and butanol. All four fractions were tested for cytotoxicity using MTT method and the absorbant was measured at wavelength of $595 \mathrm{~nm}$. Further, the mechanisms of cell cycle and apoptosis induced by the most active fraction were analyzed using Fluorescence-Activated Cell Sorting with marker (probe) propidium iodine (PI) and annexin V. The results showed that the cytotoxicity of CGRE on WiDr cell line was $44.2 \mu \mathrm{g} / \mathrm{ml}, \mathrm{F} 1\left(\mathrm{IC}_{50} 0,367 \mu \mathrm{g} / \mathrm{ml}\right), \mathrm{F} 2\left(\mathrm{IC}_{50} 0.063 \mu \mathrm{g} / \mathrm{ml}\right), \mathrm{F} 3\left(\mathrm{IC}_{50} 0.18 \mu \mathrm{g} / \mathrm{ml}\right)$, and F4 (IC 50 $2.24 \mu \mathrm{g} / \mathrm{ml})$. WiDr cells treated with F2 caused changes in the cell cycle profile through an increased G2/M phase ( $38.18 \%)$, increased cell apoptosis $(20.05 \%)$ and increased expression of caspase-8 $(27.4 \%)$. In conclusion, F2 of CGRE exhibited anticancer activity against WiDR cell through Cell cycle arrest G2/M phase enhancement and increased expression of caspase- 8 , that resulted in an increased cell apoptosis.
\end{abstract}

\section{INTRODUCTION}

Treatment of colon cancer has been intensified with surgery, chemotherapy and radiotherapy. However, such treatment is not able to effectively cope with cancer. Failure in the treatment of cancer by chemotherapy, for instance is due to low selectivity of anticancer drugs to normal cells, causing serious side effects in patients. Moreover, the failure of chemotherapy was also caused by resistance of cancer cells to chemotherapeutic agents. Such resistance has consequences for increasing therapeutic dose (Conze et al., 2001). Appropriate therapeutic strategies are needed to overcome these problems. The discovery of new drugs which have specific molecular targets with very high selectivity is needed to address the above

* Corresponding Author

Email: Sukardiman @ ff.unair.ac.id problems. In general, selection of therapeutic targets in cancer cells is based on changes in the molecular regulation of cancer cells. Therefore, the present study investigated two main targets i.e. induction of cell apoptosis and cell cycle regulation. Apoptosis is programmed cell death and plays an important role in maintaining homeostasis of human body. Failure of apoptosis is the main factor of malignancy of cancer cells. Cancer treatment through induction of apoptosis has been known to prevent promotion, progression and reappearance of cancer (Rastogi and Sinha, 2009). Induction of apoptosis is not only used in chemotherapy, but also for chemoprevention (Hsia et al. 2005). Some compounds isolated from plants that have been known to be as effective as chemotherapy by inducing apoptosis include curcumin from Curcuma longa plant, aloe-emodin from aloe-vera plant, and cinnamaldehyde of the plant Cinnamomum cassia (Rastogi and Sinha, 2009). 
In addition, it has also been reported that calotropin isolated from Calotropis procera is able to inhibit the growth of $\mathrm{K} 562$ cancer cells through induction of apoptosis (Wang et al., 2008; Huang et al, 2012). Based on this approach, Calotropis gigantea, similar to Calotropis procera, also contains Calotropin and therefore, might also be potential as an anticancer through induction of apoptosis. Previous studies showed that root extract of Calotropis gigantea have higher anticancer activity than leaves and flowers extract with $\mathrm{IC}_{50} 44.2 \mu \mathrm{g} / \mathrm{mlon}$ breast cancer T47D Cell Line (Muti et al., 2016). Ethyl acetate fraction from Calotropis gigantea leaves exhibited a potent cytotoxic effect on Human Colon Cancer WiDr cells line (Mutiah et al., 2017). These statement are still needs to be further Investigated especially on roots ethanolic extract .This study therefore sought to determine the mechanism of apoptosis induced by the most active fraction of Calotropis gigantea root extract in colon cancer cells WiDr.

\section{MATERIALS AND METHODS}

\section{Materials and Reagents}

Materials in this study were the roots of Calotropis gigantea harvested from Pasuruan, East Java. Scientific determination has been certified by LIPI (LembagaIlmu Pengetahuan Indonesia) Purwodadi Malang, East Java Indonesia.

Solvents used for maceration was $70 \%$ ethanol (Merck, Indonesia). Fractionation process used ethyl acetate p.a (Merck, Indonesia), Chloroform p.a (Merck, Indonesia), butanol p.a (Merck, Indonesia) and distilled water. Colon cancer cell line was WiDr obtained from Cancer Chemoprevention Research Centre (CCRC), Gadjah Mada University Faculty of Pharmacy and Prof. Masasi Kawaichi, Laboratory of Gene Function in Animal, Graduate School of Biological Sciences, Nara Institute of Science and Technology, Japan. WiDr cells in a medium of Rosewell Park Memorial Institute (RPMI) supplemented with $10 \%$ heatinactivated fetal bovine serum (FCGS) (PAA laboratories, Netherlands), $1 \%$ v/v penicillin-Streptomycin (NacalayTesque, USA), and 1,0mM L-glutamine (NacalayTesque, USA). The cells were cultured in the incubator, at $5 \% \mathrm{CO}_{2}, 95 \% \mathrm{O}_{2}$ at $37^{\circ} \mathrm{C}$.

Dimethyl sulfoxide (DMSO), were used to dissolve the extract of Calotropis gigantea. The concentrations used in this study a maximum of $1 \%$ in the culture medium. A $0.025 \%$ trypsin in the culture medium was used to harvest cells. Phosphate buffered saline (PBS) was used as wash buffer solution. 3- (4,5dimetiltiazole-2-yl) -2,5-difeniltetrazolium bromide (MTT) was used as a reagent that reacts with the enzyme succinate dehydrogenase in the cell. Material Testing Regulation to review cell cycle flow-cytometry method: A solution propidium iodine

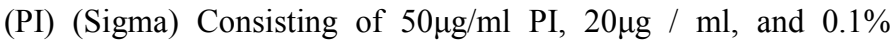
Triton-X (Pro GC-Merck, Indonesia).

Materials for review Testing Methods Induction of apoptosis flow cytometry: Solution propidium iodine (PI) (Sigma) Consisting of $50 \mu \mathrm{g} / \mathrm{ml} \mathrm{PI,} 20 \mu \mathrm{g} / \mathrm{ml}$, and $0.1 \%$ Triton-X (Pro GC-Merck, Indonesia) hearts PBS. Annexin V assay (Annexin V-
FITC Apoptosis Detection Kit Biovision, USA) and binding buffer.

\section{Extraction and fractionation}

Dried roots of Calotropis gigantea were put in solvent extraction $70 \%$ ethanol at ratio of 1:5 for 72 hours. Supernatant was filtered, and sediments was extracted again using ethanol $70 \%$ with ratio of 1: 2for 72 hours. Re extraction was done twice. Obtained filtrate was collected and evaporated under reduced pressure to obtain a concentrated ethanol extract. The obtained extract was mixed with $100 \mathrm{ml}$ distilled water to obtain liquid extract from ethanol. Extracts were then fractionated by dichloromethane 100: 500 (extract water; dichloromethane) yielded two fractions, namely dichloromethane soluble and insoluble fractions. Dichloromethane insoluble fraction was fractionated using ethyl acetate ratio of 100:600 (insoluble fraction dichloromethane: ethyl acetate), which resulted in ethyl acetate insoluble and soluble fraction. Insoluble Fraction of ethyl acetate were mixed with butanol with ratio of 100: 600 (insoluble fraction of ethyl acetate: butanol). The final product was butanol fraction and water fraction. The four fractions were evaporated with a rotary evaporator to get a concentrated extract. Fraction was then dried using freeze drying to remove excess solvent residue

\section{Cytotoxic test with MTT method}

Suspension WiDr colon cancer cells $(100 \mu \mathrm{l})$ with a density of $3 \times 10^{4}$ cells / $100 \mu \mathrm{l}$ media was distributed into 96-well plate and incubated for 24 hours. After incubation, the wells were added $100 \mu \mathrm{l}$ test solution with serial concentrations : 50, 25, 12.5, $6.25,3.75,1.875 \mu \mathrm{g} / \mathrm{ml}$. For positive control was added $100 \mu \mathrm{l}$ of culture medium, then $100 \mu \mathrm{l}$ of Doxorubicin on the various series of concentrations in wells already containing $100 \mu \mathrm{lml}$ cell suspension.

As a control cell was added $100 \mu \mathrm{l}$ culture medium in wells containing $100 \mu \mathrm{l}$ of the cell suspension. As a control, $100 \mu \mathrm{l}$ of DMSO was added in wells containing $100 \mu \mathrm{lml}$ of culture medium and $100 \mu \mathrm{l}$ of cell suspension with dilutions accordance with dilutions concentration of the test solution.Samples were then incubated for 24 hours in an incubator with $5 \% \mathrm{CO}_{2}$ and $95 \% \mathrm{O}_{2}$. At the end of incubation, culture medium was discarded and then added $10 \mu \mathrm{l}$ solution of MTT (5 mg / mlin PBS), and the medium was replaced with $190 \mu 1$ of medium RPMI 1640 complete. The cells were incubated for 3-4 hours. MTT reaction was stopped by addition of SDS stopper reagent $(100 \mu \mathrm{l}$ Microplate then was wrapped with tissue and incubated for a night in dark room at room temperature. Living cells react with MTT to form a purple colour. The test result was read by ELISA reader at wavelength of $595 \mathrm{~nm}$ (Nugroho et.al.,2013).

\section{Data analysis anticancer activity}

Data obtained in the form of pitting each absorbance converted to a percent of cell viability 
viability cell

$=\frac{\text { absorbance treatment }- \text { absorbance of control media }}{\text { absorbance of control cell }- \text { absorbance of control media }} \times 100 \%$

Percentage of cell viability is calculated to obtain the $\mathrm{IC}_{50}$ value. $\mathrm{IC}_{50}$ is the concentration that caused growth inhibition of $50 \%$ of a population of cells that can be known cytotoxic potency. $\mathrm{IC}_{50}$ values were determined by probit analysis (Statistical Product and Service Solutions (SPSS) 16.0 for Windows)

\section{Cell cycle analysis by flowcytometry}

Cell cycle were analysed using dye propidium Iodide (PI). These dyes can be used to analysis a set amount of DNA in each cell. Cells as $5 \times 10^{5}$ cells / well were grown in 6-well plate and then incubated. Cells were treated with DMSO (0.25\%) and active isolates, and measured for $\mathrm{IC}_{50}$. Cells were incubated for another 24 hours. At the end of the incubation, the media was taken and transferred to tube and centrifuged at $(2000 \mathrm{rpm}, 3 \mathrm{~min})$.The supernatant was discarded. The medium in well was and replaced with PBS.

The PBS was then transferred to the same micro tube, centrifuged and the supernatant was discarded. This stage was repeated once and then the cells were harvested with trypsin. The cells were transferred into the same micro-tube and centrifuged at (2000 rpm, 3 minutes). Remaining cells that were in the wells were washed with PBS and centrifuged again. Deposition of cells in micro-tube was then fixed with $70 \%$ ethanol, at $-20^{\circ} \mathrm{C}$, incubated for $30 \mathrm{~min}$ at room temperature. Samples were then centrifuged at (2000 rpm, 3 minutes). The precipitated cells were washed with PBS twice and PI reagent was added carefully, and immediately homogenized. Micro-tube containing cell suspension was wrapped in aluminum foil and incubated in water bath at $37^{\circ} \mathrm{C}$ for 20 minutes. The cell suspension was homogenized and transferred back into the flow-cytometer tube using nylon filters, then ready for analysis.

\section{Analysis of cell Apoptosis induction by flow-cytometry}

Cells as $5 \times 10^{5}$ cells / well were grown in 6-well plate and then incubated back to normal. Cells were treated with DMSO $(0.25 \%)$. Cells were then incubated for another 24 hours. At the end of the incubation period, the media was taken and transferred to the tube, and centrifuged at (2000 rpm, $3 \mathrm{~min})$. The supernatant was discarded.

The medium in well was removed and replaced with PBS. The PBS was transferred to the same micro-tube, centrifuged and the supernatant was discarded. This stage was repeated once and then the cells were harvested with trypsin. The cells were transferred into the same micro-tube and centrifuged at (2000 rpm, 3 minutes).

Remaining cells in the wells were washed with PBS and centrifuged again., Reagent PI-Annexin V was carefully added and immediately homogenized. Micro-tube containing cell suspension was wrapped in aluminum foil and incubated in water bath at $37^{\circ} \mathrm{C}$ for 5 minutes. The cell suspension was homogenized and transferred back into the flow cytometer tube using nylon filters, and ready for analysis.

\section{RESULTS AND DISCUSSION}

In the study, fractionation to those extract was done using chloroform, ethyl acetate, butanol and water as solvent, yielding four fractions. They were Chloroform fraction, ethyl acetate fraction butanol fraction and water fraction. From its fraction we evaluated anticancer activity on widr cell line colon cancer.

Based on the analysis, the $\mathrm{IC}_{50}$ of each fraction were as follow: fraction $1\left(\mathrm{IC}_{50}: 0,367 \mu \mathrm{g} / \mathrm{ml}\right)$, fraction $2\left(\mathrm{IC}_{50}: 0.063 \mu \mathrm{g} / \mathrm{ml}\right)$ fraction $3(0.180 \mu \mathrm{g} / \mathrm{ml})$, all has high anticancer activity, whereas fraction $4\left(\mathrm{IC}_{50}: 2.237 \mu \mathrm{g} / \mathrm{ml}\right)$ had no anticancer activity. It is also supported by absence of morphological changes in cells after treatment. From these data, it can also be known that fraction 2 has a stronger activity than fraction 1 and 3. From morphology figure 1 , it showed that cells died as they were not attached to the plate, and the cells membrane look harsh and blebbing.

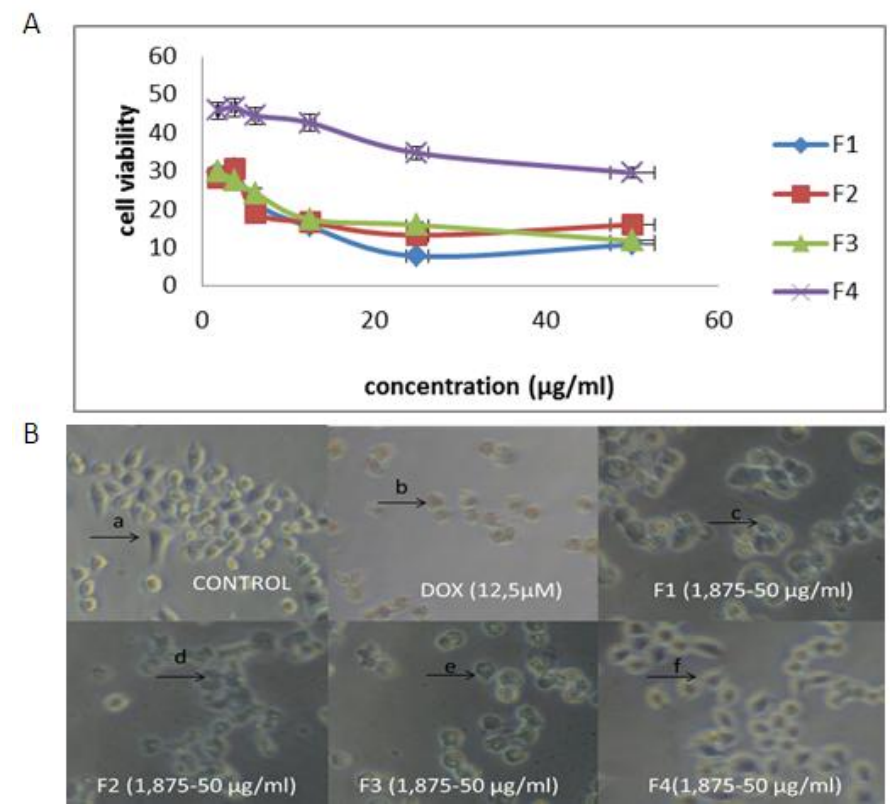

Fig. 1: (A) Themorphology of cell was examined under microscope (x400) (B) The inhibition effect of colon cancer cell after treatment with F1 (dichloromethan fraction), F2 (ethyl acetate fraction), F3 (butanol fraction), and F4 (water fraction). The changes after treatment with F1, F2 and F3 were blebbing (b,c,), enlarged (d) and stringy (e). Viable cells was seen in control treatment (a) and F4 treatment (f). Each point was mean \pm SD of three experiments

Table 1: $\mathrm{IC}_{50}$ of Roots fractions of Calotropis gigantea incubated with colon cancer line WiDr.

\begin{tabular}{cc}
\hline Samples & IC50 ${ }^{*}(\boldsymbol{\mu g} / \mathbf{m l}) \pm$ SD \\
\hline Ethanol extract & $44.20 \pm 2.39$ \\
F1 & $0.367 \pm 0.039$ \\
F2 & $0.063 \pm 0.040$ \\
F3 & $0.18 \pm 0.077$ \\
F4 & 2.2371 .06 \\
Doxo & $9.27 \pm 0.57$ \\
\hline
\end{tabular}

$*$ Values are mean \pm SD of triplicates. 
Treatment of cells with F1, F2 and F3 have caused morphological changes in WiDr cells, and these changes were linear with the increasing concentrations of extract. In normal WiDr cells (control), their cytosol looked oval with clear and attached to the base of Tissue Culture Dish (TCD). After treatment of F1, F2 and F3, some cells appearances were rounded and detached from TCD. Cells were cloudy and compact, as they might experienced condensation, core shrinkage and granulation in the cytosol. The morphological changes were more pronounce in line with increasing concentrations of the test. In line with changes in the morphology, treatment with F1, F2 and F3 has also decreased cell viability which were linear with the increasing concentrations of the test. Treatment with F4 resulted no visible morphological changes in cells, where they weres till oval with clear cytosol and attached to the base of Tissue Culture Dish (TCD).

To determine whether the anti-proliferative effect was caused by F2, it can be directed to the resting phase; by investigated further necessary changes in cell cycle distribution analysis. Cell cycle analysis was conducted using FluorescenceActivated Cell Sorting using marker (probe) of propidium iodine (PI). From the results of analysis, it showed that treatment with F2 has caused an increased accumulation of cells in G2/M phase by $38.18 \%$ compared to control $(12.1 \%)$. The results of the cell cycle analysis and apoptosis of cells were presented in the figure 2.

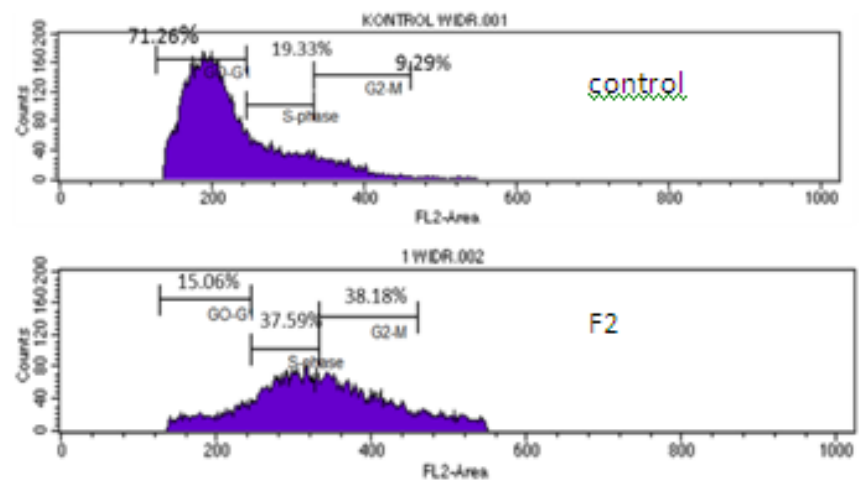

Siklus Sel (F2)

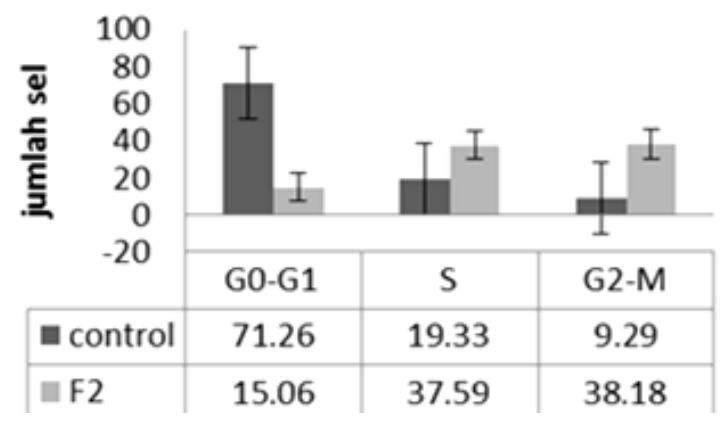

Fig. 2: the effect of induction of cell death and changes in the distribution of cell cycle phases after treatment with F2. Distribution Profile of each phase (G1, M, and G2 / M) in the cell cycle was analyzed using flow-cytometry with propidium iodide staining (PI). Accumulation of cells in G2/M showed induction of cell death.
Observations on the induction of apoptosis was carried out to determine the cause of death of both apoptosis and necrosis cells. Flowcytometry method is able to distinguish between living cells, early apoptosis, late apoptosis and necrosis, due to reagent Annexin V and PI work that selectively bound to cells, regardless they were intact or not intact (fragmentation). The test results showed that treatment of WiDr cancer cells with F2 has caused an increased cell apoptosis by $20.05 \%$ whereas in control was $4.6 \%$ (Figure 3).
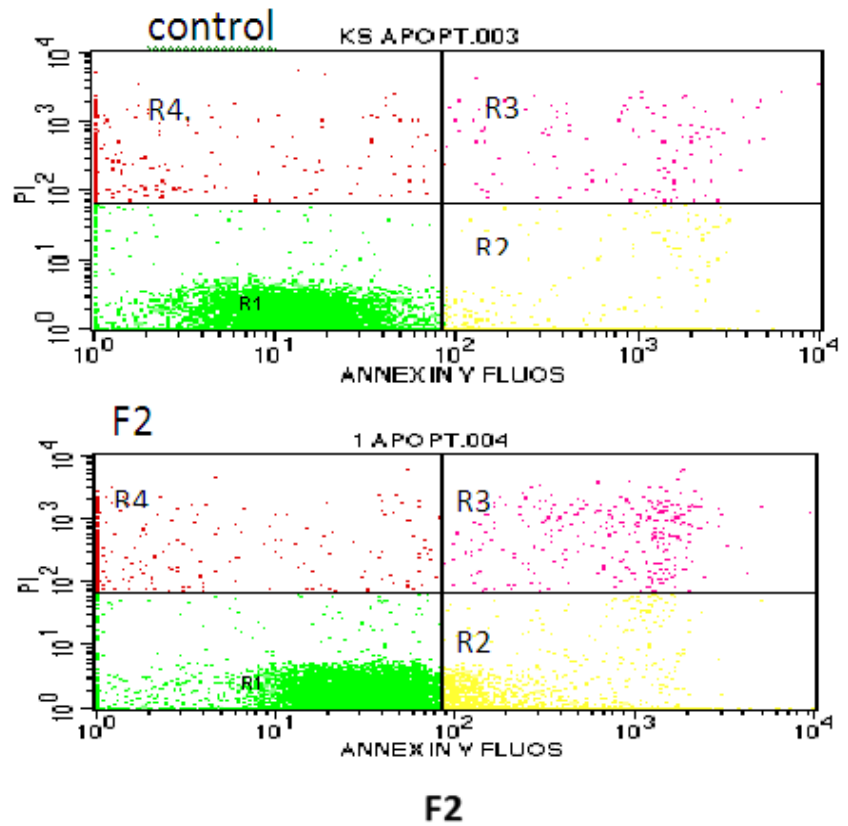

apoptosis necrosis

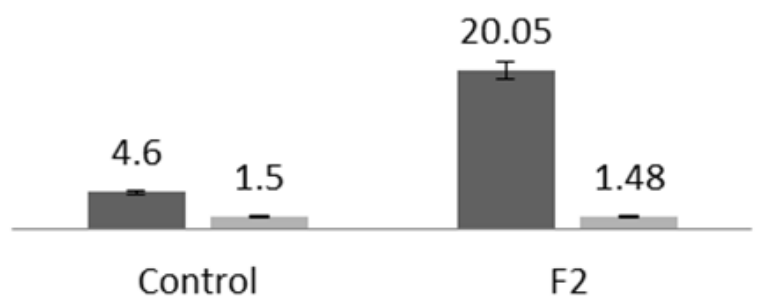

Fig. 3: Distribution of cells and analysis of induction of cell death / cell quest by using flowcytometry. (A) control WiDr cells (B) treatment with F2 to WiDr cells:(R1) living cells, (R2) early apoptosis, (R3) apoptosis end, and (R4) necrosis.Cells were exposed to either medium or extracts (at its $\mathrm{IC}_{50}$ concentration) and incubated for $24 \mathrm{~h}$. Apoptotic population was determined by Annexin- $\mathrm{V}$ assay.

In cell cycle analysis, it showed that treatment of WiDr cells with F2 inhibited cell proliferation, indicating by an increasedG2/M phase. The increase in the resting phase was in line with the progressive increase of cell apoptosis. To determine the mechanism of the cell cycle change and apoptosis induction, immunocytochemistry analysis was used to see the expression of caspase-8. The results showed that treatment with F2 increased expression of the caspase- 8 by \% (Figure 4 ). 

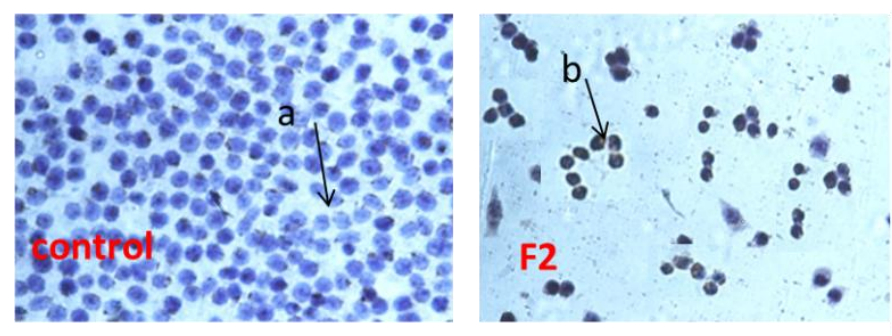

F2

- Ekspresi caspase-8 (\%)

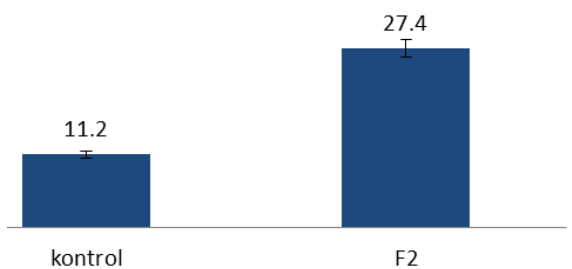

Fig. 4: F2 CGRE Treatment Effects on Expression of caspase-8 in WiDr cells using immuno-cytochemistry. (A) Control cells without caspase- 8 antibody, (B) Cells treated with F2 and anti Caspase- 8 showed increased protein expression of caspase-8 seen from the cell nucleus with dark purple colored. The arrow shows the expression of caspase- 8 . The microscope used was a light microscope with a magnification of $400 x$.

Induction of apoptosis in cancer cells is a key strategy in cancer therapy. Changes in cell morphology at the induction of apoptosis is indicated by a membrane blebbing, cytoplasm shrinkage and chromatin condensation. DNA fragmentation is a major indicator in the process of apoptosis induction. At the molecular level there are several major indicators in apoptosis; one them is the expression of caspase- 8 in the extrinsic pathway. Pathway apoptosis is caused by extrinsic pathway via Fas death receptor. Activation of Fas by Fas ligand (FasL) causes activation of caspase- 8 in plasma membrane. Caspase- 8 breaksthe inactive form of Bid into two parts; the part containing BH3 domain is the active form of Bid (tBid). Protein tBid is translocated to mitochondria and stimulate the release of Cyt $\mathrm{c}$ which then forms a complex with Apaf-2 to activate caspase-8, and causes apoptosis(Cullen and Martin, 2009; Tait and Green, 2010).

\section{CONCLUSION}

We concluded that F2 CGRE inhibited WiDr cells proliferation with $\mathrm{IC}_{50} 0.063 \mu \mathrm{g} / \mathrm{ml}$. Inhibition mechanism was through induction of apoptosis, indicated by the increased G2/M $(38.18 \%)$ and increased expression of caspase-8 (27.4\%).

\section{ACKNOWLEDGEMENT}

\section{Financial support and sponsorship}

We deeply thank the DP2M DIKTI (Directorate of Higher Education) Ministry of Education, Indonesia, for their financial support through "HIBAH KERJASAMA PERGURUAN TINGGI (PEKERTI)" Research Grant in 2014 that made this study possible.

Conflict of Interests: There are no conflicts of interest.

\section{REFERENCES}

Nugroho, AE., Hermawan, A., Putri DDP.,Novika A. Combinational effects of hexane insoluble fraction of Ficus septica Burm and doxorubicin chemotherapy on T47D breast cancer cells Combinational. Asian Pacific Journal of Tropical Biomedicine, 2003; 3(4): 297-302.

Conze D., Weiss L., Regen PS, Bushan A, Weaver D, Johnson P, Rincond M. Autocrine Production of Interleucin-6 causes multidrug resistance in breast cancer cell. Cancer Res. 2001.

Cullen, S.P. and Martin, S.J., Caspase activation pathways: some recent progress. Cell Death and Differentiation, 2009; 16(7): 935938.

Hsia, H.C., Schwarzbauer, J.E., Papers, J.B.C., Meet the Tenascins : Multifunctional and Mysterious. 2005; 26641-26644.

Muti, R., Sukardiman., Widyawaruyanti, A., Zulaikah, S., Comparison of Ethanol Extract from Roots Leaves and Flowers ofCalotropis gigantea as Anticancer on T47D Breast Cancer Cell Lines. Alchemy, 2016; 5(1): 1-4.

Mutiah, R., Sukardiman, Widyawaruyanti, A., Cytotoxic effect of crude extract and fraction from Calotropis gigantealeaves on human colon cancer widr cell lines.International Journal Pharmacy and Pharmaceutical Sciences. 2017; 9(1): 83-84.

Rastogi, R.P. and Sinha, R.P. Apoptosis: molecular mechanisms and pathogenicity. 2009; 8: 155-181.

Tait, S.W.G. and Green, D.R., Mitochondria and cell death: outer membrane permeabilization and beyond. Nature Reviews Molecular Cell Biology, 2010; 11(9): 621-632.

Huang M., Lu JJ., Huang MQ., Bao JL., Chen XP, Wang YT. Terpenoids : natural products for cancer therapy. 2012; 1801-1818.

Wang, ZN.,Wang, MY., Mei, WL., Han, Z., Dai FH., A new cytotoxic pregnanone from Calotropis gigantea. Molecules, 2008; 13(12):3033-3039.

\section{How to cite this article:}

Mutiah R, Widyawaruyanti A, Sukardiman S. Ethyl acetate fraction of Calotropis gigantea roots induce apoptosis through increased G2/M and increased expression of caspase- 8 in colon cancer WiDr cell line. J App Pharm Sci, 2017; 7 (07): 197-201. 